\title{
Pritzker is not enough:
}

\section{Braga Stadium and the city-branding that was not}

Guilherme Rene MAIA, University of Coimbra, Portugal

\begin{abstract}
It is well known that sports mega-events are widely used as city, even country branding tools: this is the case of UEFA EURO 2004, when Portugal - one of smaller economies of UE - built ten stadiums to receive the most important football championship in Europe. Some Portuguese cities saw the opportunity to promote expansion of urban areas or host international entertainment events; some football clubs saw it as way to update or build new stadiums, with the prospect of use them not as simple sport venue, but as multi-purpose arenas and touristic attraction. The city of Braga asked Eduardo Souto de Moura, then an internationally renowned architect, to design the stadium, which paved the way to his author win the Pritzker Prize in 2011. Despite that, the stadium is heavily criticized by SC Braga, its tenant and the city, its owner: it is considered an unprotective cold place; and, above anything else, it was the most expensive per seat of those built for UEFA EURO 2004. The study is part of author's PhD thesis currently in development and was realized with basis on stakeholder's interviews, academic and press files research.
\end{abstract}

\section{Keywords}

Megaevents, Legacy, Planning education 
Like Jefferson, tonight's honoree spent his career not only pushing the boundaries of his art but doing so in a way that serves public good. (...). Perhaps, Eduardo's most famous work is the stadium he designs in Braga, Portugal. Never want to settle for the easy answer, Eduardo wants to build this particular stadium on the side of a mountain. So, he blasted out nearly a million and a half cubic yards of granite of the mountain side, then crushed it to make the concrete necessary to build the stadium. He also took great care to position the stadium in some way that anyone who couldn't afford the ticket could watch the match from the surrounding hillsides, kind of like Portugal's Wrigley Field. And that combination of form and function, of artistry and accessibility is why today we honored Eduardo with what is known as the Nobel Prize of Architecture. (..). I want to thank all the men and women who create this timeless works of art. Not only to bring us joy but help to make this world a better place

Barack Obama, 44 $4^{\text {th }}$ President of USA, during speech at 2011 Pritzker Prize Award Ceremony - $2^{\text {nd }}$ June 2011

\section{Introduction}

The present paper discusses the case of Braga, one of ten cities that bet through landmark creation as tool for city branding, with the hosting of UEFA EURO 2004 in Portugal as background. It starts through the history of Portuguese bid, its implications at national and regional political level; then, focuses on design and construction of the Estadio Municipal de Braga, its constrains and deviations; next, presents the building status, internationally awarded, and locally hated. It concludes with a reflection on why the city still can benefit from it as cultural asset.

\section{From Switzerland with love}

It is well known that sports mega-events are widely used as city, even country branding tools: this is the case of UEFA EURO 2004, when Portugal - one of smaller economies of UE - built or retrofitted ten stadiums to receive the most important football championship in Europe(Balsas, 2018). For the 2004 edition, three applications were admitted: Spain launched its bid in 1996; Austria and Hungary joint application started in 1997 and Portugal launched its bid on 1 June 1998, in the height of a successful organization of EXPO 1998, held in Lisbon. On 12 October 1999, UEFA announces Portugal as host of the 12th edition of Men's European Football Championship in June/July 2004 (RTP, 1999).

Public commitment of government with the championship's organization - which counted also with opposition support; a growing economy then; a peaceful society, with no records of violence in football or terrorism threatens; new and qualified infrastructures of transport and communication; wide hotel network of all dimensions and characteristics, that keeps on growing and improving; even weather, hospitality and gastronomy were pointed by UEFA as major reasons to the success of Portuguese bid. The high level of political commitment is documented on Resolution of the Council of Ministers Relating to Portugal's Application to Organize the European Football Championship (Presidência do Conselho de Ministros, 1998), an official communication that have the power to guide and support major administrative decisions within Portugal government, from budget to law enforcement. This document was signed by then Prime Minister Antonio Guterres (now UN General Secretary), by then Minister of Sports José Sócrates (that will become Portuguese Prime Minister between 2005/2011) and Gilberto Madail (President of Portuguese federation of Football between 1996/2011).

The Portuguese government forecasted as positive results from the 2004 EURO the strengthening of economy, as (...) This would be seen by growth in the tourism industry and other rapidly 
developing key industries such as telecommunications and new technologies, by increased job creation, both direct and indirect, and by linking modernization of football stadiums to urban renovation initiatives which would have a positive impact at a local level. (...)(UEFA, 2000): it reflected, in national level, on transportation development, being it railroad improvement or roads and bridges construction. Cities saw, with different levels of success, the opportunity to promote expansion or renewal of urban areas beyond the venue. Loulé, Aveiro, Braga, Porto were host cities that have developed urban schemes were the stadiums act as major anchors. Football clubs saw it as way to update or build new stadiums, with the prospect of use them not as simple sport venue, but as multi-purpose arenas and touristic attraction, as some of its Spanish and English counterparts did. All that appetite was fuelled by less demanding financial controls of late 1990's: the prospect of a newer and strong European common currency plus the money influx aimed to level the differences between members were the financial background for those investments.

Portugal nomination has also a role on European politics, as explicitly pointed by UEFA: "It doesn't make sense anymore to keep on concentrating the responsibility of organizing the great European and even worldwide football competitions in a reduced number of countries. And we believe that a strong Europe (ie. UEFA) depends more and more on the existence of a growing number of strong countries." (UEFA, 2000). That statement fits perfectly on the sense of a New Europe, with a forecast of common currency. Prime Minister Antonio Guterres reinforces UEFA statement "As host of the last Universal Exhibition of both the century and the millennium, EXPO98, was a symbol of our ability, modernity and dynamism, (...) In 2004, we wish to demonstrate this hospitality and warmth once again, as organizers of the European Football Championship. We have all that is needed - the facilities, the enthusiasm, and above all, the passion"(UEFA, 2000).

Such passion is based on a tradition - although challenged- that Portugal claims to have of national teams and clubs in international competitions. What is indisputable, however, are the strong connections between politics and football clubs in all levels (Kumar, R., 2007): clubs of bigger cities have representatives identified on national stage; smaller and medium cities clubs are convergence points on local politics. It helps explain the record number of ten stadiums built or "retrofitted" for the 2004 EURO. Five stadiums belong to football clubs - with four on the two major Portuguese cities of Lisbon and Oporto and five stadia public owned but privately operated by football clubs and associations. Between November and December of 2001, Portugal 2004 (a joint venture of UEFA, Portuguese federation of Football and Portuguese Government) signed the contracts with the ten local hosts (Instituto Nacional do Desporto, 2001); in March of 2003, UEFA approved all the stadia developed to receive the matches.

\begin{tabular}{lllll}
\hline Stadium & City & $\begin{array}{l}\text { Proposed } \\
\text { capacity (bid) }\end{array}$ & $\begin{array}{l}\text { Current } \\
\text { capacity }\end{array}$ & $\begin{array}{l}\text { Total cost in } \\
\text { 2004 (euros) }\end{array}$ \\
\hline Luz & Lisbon & $70.000+$ & 65.647 & $153.541 .046,00$ \\
\hline José Alvalade & Lisbon & 43.000 to 52.500 & 50.095 & $128.048 .300,00$ \\
\hline \hline Dragão & Oporto & $50.000+$ & 50.033 & $123.318 .051,00$ \\
\hline MUNICIPAL DE BRAGA & Braga & $\mathbf{3 0 . 0 0 0 +}$ & $\mathbf{3 0 . 2 8 6}$ & $\mathbf{1 2 1 . 5 9 3 . 6 0 1 , 0 0}$ \\
\hline Municipal Magalhães Pessoa & Leiria & $30.000+$ & 23,888 & $76.978 .145,00$ \\
\hline Municipal de Aveiro & Aveiro & $30.000+$ & 32.830 & $62.487 .982,00$ \\
\hline Bessa XXI & Oporto & $30.000+$ & 28.263 & $54.724 .642,00$ \\
\hline Cidade de Coimbra & Coimbra & $30.000+$ & 29.622 & $52.940 .648,00$ \\
\hline Intermunicipal do Algarve & Faro/Loulé & $30.000+$ & 30.305 & $46.435 .068,00$ \\
\hline Dom Afonso Henriques & Guimarães & 30.690 & 30.029 & $37.301 .575,00$ \\
\hline
\end{tabular}

Figure 1 - Stadiums built/retrofitted for EURO2004. Source: (UEFA, 2000; Viseu et al., 2004) 


\section{For their eyes, only}

In 2001, FIFA has published in cooperation with UEFA the 2nd edition of Technical Recommendations and Requirements for the Construction or Modernisation of Football Stadia (FIFA, 2001): a book that is commonly known as FIFA Handbook. It sets a series of requirements that are mandatory to anyone interested in build or invest in stadia and is followed almost blindly during events preparation processes. On first chapter, named Strategic Pre-Construction Decisions starts by setting the general concept of the stadium to be built and ties it with its economic feasibility, noting that "In all cases the style and size of a new stadium will be governed by financial resources but notwithstanding this fundamentally limiting factor there are certain basic considerations that must be recognized at the outset, e.g. (a) Is there sufficient funding available to achieve what is necessary, bearing in mind that it is pointless and wasteful to build a stadium which is so limited in terms of capacity and comfort that it cannot hope to serve the purposes for which it was originally conceived?" (FIFA, 2001). The next statement corroborates the previous, regarding attendance capacity: "It is not unusual for clubs to find that the provision of a bright, new, clean and comfortable stadium brings with it a dramatic increase in attendance levels. In such circumstances a club which normally attracts an audience of, say, around 5,000 and is thinking of building a new stadium with a capacity of perhaps 7,000 might find it preferable to think in terms of nearer 10,000. There are, of course, no absolutes in these matters and it is very much a choice of those concerned." (FIFA, 2001). Thus, the decision on the size of stadium - which is directly proportional to construction, operation, and maintenance costs - depend on owner's expectations more than their daily reality knowledge.

According to FIFA Handbook, venues should provide some level of comfort and safety to the fans, besides create the emotional and technical background to the main commercial product of both sports federations: matches' first-class broadcasting. To achieve that, stadiums should put fans closer to the action through more vertical stands; distribute them more evenly and, if needed to avoid the "holes" caused by empty seats, proactively install seats with different colours that look occupied: it is important to have the congregational spirit of Antique Rome arenas, in person and on TV. On the technical side, evenly lit play fields and stands avoid shadows and make fans visible on TV; priority for camera positioning on the stadium, reserved media spaces, such as conference rooms, organized players interview area (mixed zone) were requirements introduced by FIFA Handbook specially to improve the game as media product above all. Regarding comfort and safety of fans, FIFA Handbook translates the experience of FIFA/UEFA as event organizers and reflects the role of sport as both mass entertainment and VIP amenities, guiding clubs and federations pursuing to build a stadium that fits in a global market. To achieve this goal, stadium promoters must make it like multipurpose buildings, not just pristine standings for sports fans. In that sense, beyond covered individual seats, owners should put some effort in bring amenities such as VIP lounges, catering, exclusive parking spaces, state-of-art communications technology, among others.

The city of Braga joined the Portuguese bid to host the EURO2004 by proposing a major urban operation known as PUN - Parque Urbano Norte (North Urban Park), which have the municipal football stadium as main feature (Viseu et al., 2004). The plan for PUN contemplates, besides the stadium, an aquatic complex with covered Olympic pool; a multipurpose sports hall; tennis courts; venues for extreme sports among other equipment. It also envisions roads and infrastructures that should connect scattered urban areas to the city and region; it also contemplates the consolidation of green spaces and urban settings that should complete the scheme, which should create a new and vibrant neighbourhood in the city' north. Yet, for the 2004 event, only the stadium and road connections with national network were needed. During the bid, the city of Braga has submitted a stadium scheme developed by its technicians, which was preliminary approved; it was indeed too schematic and do not fulfil the expectations of its citizens (Maia and Grande, 2020), especially those more influential and affluent, which 
include the leaders of local football club and venue's future tenant, Sporting Club Braga - SC Braga. From the beginning, retrofit the old city stadium, known as Estádio 10 de Maio, was off the table: it would require so much sanitation and demolition work before effectively start to build the venue that was supposedly less expensive start from scratch.

\section{Licence to build}

Eduardo Souto de Moura, then just an internationally renowned architect - not a Pritzker Prize Holder yet - is approached in an anecdotic exchange with city council and hired to lead a team to design a stadium able to host two matches of group stage of UEFA EURO 2004, following the requirements of FIFA Handbook. All the process was conducted professionally by the design team, even with their lack of experience in this kind of project: travels were made around Europe to know and understand how stateof-art venues works; external consultants for specialized studies were hired; a double check, intensive $R \& D$ process by engineering were adopted. Some decisions, however, were based more in instincts then studies, lead to major cost overruns, namely the site choice and rooftop design.

The architect approach to design was deeply authorial, with his ideas supported by a personal reading of site, construction methods and from the great buildings of Architecture history - both ancient and contemporary (Maia and Grande, 2020). Site selection for the venue was made by walking in the area of the future PUN, designated to receive the stadium and noticing a quarry that "was a spectacular thing". "What if (...) I carve the stands inside the quarry?" (Maia and Grande, 2020) as the Greeks did in Epidarus, an infamous open-air theatre from ancient times. In his exercise of program interpretation, Souto de Moura read the modern football as a globalized theatre play: twenty-two actors on stage, under floodlight, being broadcasted worldwide. The stands on the quarry - his version of Epidaurus - fulfil half of audience standards set by UEFA for international competitions; to reach the remaining number, design team propose to mirror the stands across the longitudinal axis of playfield, this time fully cast in concrete. To Souto de Moura, "is not football a game played from left to the right? Then I will sit on the back of the goal and see it back and forward?" (Maia and Grande, 2020), which means no stands were designed on the shorter sides of playing field. From start, the two stands option means taller, more expensive structure to offer the same number of seats than lower, regular, four sides stand built over flat land available. Excavation started even before contract signature with Organizing Committee, relying on preliminary geological information: the raw material could be used on future concrete structures within the venue or sold to other builders. Within months, construction company find that bedrock structure was not the preferred, demanding stabilization; shortly after that, an even bigger unforeseen risk, not detectable by geological survey (Furtado, Quinaz and Bastos, 2010), was found: a layer of clay that weakens the quarry wall, demanding an even deeper reinforcement, moving the building footprint (already set literally in stone) by $20 \mathrm{~m}$ and requiring an enlargement of structures and reinforcements monitoring. Rooftop design is other polemic feature of the stadium: instead of regular, less expensive cantilevered truss cover, Souto de Moura proposed an "elegant concrete veil", as his master Siza have designed to cover the square along Portuguese Pavilion at EXPO1998: buttresses and the need to cover a public space were there, so why not explore a similar solution? Though, three main differences from Lisbon building play a crucial role in Braga: the span is almost four times bigger; there is no height condition to build it through scaffolding (more usual and less expensive building procedure of EXPO1998) and $1 / 3$ of the length have to be open to guarantee that natural grass playing surface natural light to the (Furtado, Quinaz and Bastos, 2010). All those characteristics turn the rooftop into a spectacular engineering feat, with all the special design and maintenance it requires.

Even with the quarry detour and the sophisticated roof - which were not assessed thoroughly within a value engineering process - client keep supporting entirely the concept, which can be noticed on 
the statement by Mesquita Machado, then Mayor of Braga: "evidently, we will make an exceptional work, let's make a work that interest me, that I find wonderful and will put Braga in a different stage. I am okay with that, let's do this" (Maia and Grande, 2020). Indeed, those two decisions based in empirical observations were the ones that make this stadium a unique feat: a world class football venue that push the definitions of both sports building and architecture. Under this light, Souto de Moura and his design team have created a sleek -covered theatre for 30.000 spectators, that fits harmoniously in the rocky landscape of the former quarry on southeast which he treats as domesticated landscape, adding supersized and sculptural gutters, open-ended to distant Cavado River Valley at northwest. A Pedreira The Quarry, as the stadium is known between SC Braga fans - is one of the world's most relevant buildings in the turn of the century and paved the way to his author win the Pritzker Prize in 2011, maximum honour in the field of Architecture.

\section{A view to a kill}

Despite its success as work of architecture, the Estadio Municipal de Braga, along his counterparts in Portugal is known as a massive money pit. With an initial budget of 65 million Euros, it effectively costed 175 million Euros, the 4th most expensive stadium of EURO 2004 (CM Braga, 2019). On top of that, it was funded by a loan that will be due in 2023: from the original budgeting, $33 \%$ were public funding (among city savings and funds provided by local organizer Portugal 2004) and 66\% were loans (Viseu et al., 2004) . Shortly after the EURO2004, the subprime crisis of 2008 strongly affected smaller and overfunded economies of Eurozone, as it is the case of Portugal. With all government instances drowned in debt, city of Braga, although not defaulted and with the stadium finished, was not able to build the remaining venues of PUN, exception made to roads and basic infrastructure: the Aquatic Complex started construction in 2005(Praça, 2005), but was abandoned from 2008 until 2017, when reopened converted by SC Braga in training centre - by an estimated cost of 33 million Euros at completion (Lusa, 2020) - the city have donated part of the area and concede land use rights to SC Braga . In 2019, city's current administration issued a report containing all expenses the stadium generated (CM Braga, 2019): it is almost the same amount spent on general hospital of Braga - a public-private partnership - which is far from generate the same uneasiness on taxpayers' perception of money use. Maintenance costs are about 110.000 Euros/yearly, fully supported by the city. Conservation and operation costs was covered by city until 2013, when SC Braga put the power bills under its responsibility. On revenues, SC Braga pays 6000 Euros/yearly to the city as rent (CM Braga, 2019).

Ahead of cost overrun - or magnified by it - it is the negative perception of SC Braga fans from the stadium: an unprotective cold place, far from the action and depleted of the congregational spirit that contemporary arenas promise. The first two characteristics are intrinsic to Souto de Moura architecture, but the third cannot be blamed to design: SC Braga attracted in the past ten years an average of $40 \%$ (and declining) of its stadium capacity per Campeonato Portugues match; it has the 5th best public average nationally in 2018-2019, with 12.035 attendants (39,74\%) (Liga Portugal, 2021). Overestimation of audience is not exclusive of Braga: most teams do not attract as many fans as is needed to get closer to the operation costs; in fact, only three teams and their stadiums - all private - in Portugal are capable to keep the audience average above 66\% (Liga Portugal, 2021).

With this background, the city made a huge effort to cut losses on the stadium in the following years to its opening, especially from 2013 on, when Mesquita Machado's party was defeated by the oppositionist Ricardo Rio (SIC, 2013). In 2019, local entrepreneurs presented an independent bid to buy the stadium (Jornal de Negócios, 2019): the city then proposed a referendum on venue's sale to be held in 2020 (Observador, 2019) - postponed first due to Covid pandemic then to not coincide with municipal elections (Jornal de Notícias, 2020). In April 2021, SC Braga proposed to leave Estádio de Braga and to 
retrofit the old Estadio 10 de Maio - at estimated cost of 60 million euros in own resources (Tribuna Expresso, 2021). The proposal consists of maintaining external façades, rebuild the stands to be closer to playing field and cover them with a metallic rooftop. It implicates also in demolish the athletic track. Additionally, SC Braga proposes to build hotel and office buildings around the stadium in exchange for 80year land use rights over the site. Mayor of Braga refused the idea but agreed that "This will, transmitted to me by the president [of the club] corroborates a conclusion that many people from Braga had already drawn, which is that the new Municipal Stadium was a waste of public resources, which does not even serve SC Braga", but "he even said he had already rejected the idea, clarifying that the objective of the municipal executive is "the rehabilitation" of the stadium designed by Souto Moura" (Tribuna Expresso, 2021).

\section{Conclusion: can you live twice?}

It is clear that large and complex projects present proportionally sized challenges, especially on managing of stakeholder's expectations (Vogwell, D, 2003), magnified by an enclosed context of politics and personal interests. Braga's commitment to host EURO2004 was founded over expectations mismatch: city council were interested in build city branding through landmark architecture, something that "puts Braga in a different stage" (Maia and Grande, 2020); SC Braga, at the time, made no objection on design and had seized the opportunity to have available, practically for free, a world class venue to host its matches. FIFA and UEFA just wanted their requirements satisfied, especially on broadcasting; their commitment on troubling subjects such as funding and legacy was restricted to provide guidelines, leaving the decision power on local organizer's hands. Souto de Moura and his team did what was expected from them: unbounded, they were able to design what he understood of football events, monumental landscape features and lessons learned from great construction achievements, creating a magnificent work of architecture; it is precisely the lack of limits that enabled the naïvete of design process, which lead to decisions made with good intentions but without proper assessment or discussion. With all the top-down decisions and omissions, the process resulted in a fully functional building, internationally awarded but considered a burden to the current Mayor and a cold, unpleasant stadium to SC Braga managers.

Apparently, Braga learned from some of its mistakes: the city is bidding to host the 2027 European Capital of Culture (ECC), a major event according to Müller (Müller, 2015). This bid seems to be more inclusive and participative then the one for EURO2004. Now, several groups and public agents beyond city council are engaged with event planning and developing; there is also a strong incentive to involve the community in the process. The campaign to host the ECC could be a turning point on the relationship of the city and the stadium: even if it is tremendously painful, Braga could - after almost twenty years and with loan payments near to the end - take the opportunity, forget the sunken cost (Behavioral economics, 2015) and look forward, gaining over the world-class architectonic and landscape unique features that the building has and leveraging it as cultural asset. The stadium belongs to the city SC Braga, by his own means, is just a tenant with unfulfilled potential; it is city' responsibility keeping the venue active: it takes a little imagination, some responsible planning and minor investment (compared to its construction) to take full advantage from the venue's architectural and landscape features. Beyond hosting only football matches, it can stage several open-air sports events and artistic manifestations, from boxing matches and skating presentations to concerts and multimedia interventions using mapped projection, for instance: it can be really a multipurpose building, serving its community, as some of his Portuguese counterparts will never achieve to become.

However, the bid is weakened precisely by simply ignoring the existence of the Estadio Municipal de Braga. It is quite strange that ECC organizing committee - an event that have culture and, for extension, debate over cultural matters in his core - do not invite to discuss the building, neither 
mentioning it as city' cultural asset nor proposing a way to envision it as one (Braga'27, 2018). In one hand, Braga community claims that (...) Two thousand years of History do not deter us from imagining the future(...) (Braga'27, 2018) but in other, it actually not able to subject themselves to reflect on and overcome twenty years of misunderstanding and unrefundable expenditure to move forward. Sadly, Braga seems not willing to learn what public good is.

\section{Acknowledgements}

I would like to thank my supervisor at University of Coimbra, Nuno Grande, for the initial idea for this paper and all further support. I would like also to thank University of Coimbra over the funding of the paper submission and congress participation.

\section{References}

Balsas, C.J.L. (2018) 'Country Marketing and Planning Implications of the European Soccer Championship EURO 2004.', Journal of Urban Technology, 25(3), pp. 29-29-46. doi:10.1080/10630732.2017.1284984.

Behavioral economics (2015) Sunk cost fallacy, BehavioralEconomics.com / The BE Hub. Available at: https://www.behavioraleconomics.com/resources/mini-encyclopedia-of-be/sunk-cost-fallacy/ (Accessed: 30 August 2021).

Braga'27 (2018) Braga'27, Braga'27. Available at: https://braga27.pt/en/ (Accessed: 14 September 2021).

CM Braga (2019) Report on Estádio Municipal de Braga. Available at: https://www.cmbraga.pt/pt/0201/home/noticias/item/item-1-10069 (Accessed: 8 September 2021).

FIFA (2001) Technical Recommendations and Requirements for the Construction or Modernisation of Football Stadia. 2nd edn. Zurich: Fédération Internationale de Football Association (FIFA).

Furtado, R., Quinaz, C. and Bastos, R. (2010) 'The New Braga Municipal Stadium', p. 28.

Instituto Nacional do Desporto (2001) Contrato 2701/2001, 2001-12-04, Diário da República Eletrónico. Available at: https://dre.pt/web/guest/pesquisa/-/search/3689815/details/normal?filterEnd=2004-1231\&sort=whenSearchable\&filterStart=1998-09-

03\&sortOrder=ASC\&q=uefa\&filterAction=TRUE\&fqs=braga\&fqs=uefa\&perPage=25 (Accessed: 26 August 2021).

Jornal de Negócios (2019) Pedreira pode vir a ser "Estádio das Mulheres". Available at: https://www.jn.pt/local/noticias/braga/braga/pedreira-pode-vir-a-ser-estadio-das-mulheres10575035.html (Accessed: 8 September 2021).

Jornal de Notícias (2020) Câmara de Braga desiste de referendo sobre venda do estádio municipal. Available at: https://www.jn.pt/local/noticias/braga/braga/camara-de-braga-desiste-de-referendo-sobrevenda-do-estadio-municipal-12085512.html (Accessed: 2 September 2021).

Jornal Público (2003) Braga vai ter piscina olímpica no Parque Norte até 2006, PÚBLICO. Available at: https://www.publico.pt/2003/11/25/jornal/braga-vai-ter-piscina-olimpica-no-parque-norte-ate-2006208184 (Accessed: 29 August 2021). 
Kumar, R. (2007) O futebol e a política em Portugal: para além de uma crítica moral - Le Monde Diplomatique - Edição Portuguesa. Available at: https://pt.mondediplo.com/spip.php?article77 (Accessed: 8 September 2021).

Liga Portugal (2021). Available at: https://www.ligaportugal.pt/pt/liga/estatisticas/espectadores/clube/20092010/ligasagres (Accessed: 2 September 2021).

Lusa (2020) Cidade Desportiva do Sp. Braga custará 33,5 milhões de euros, PÚBLICO. Available at: https://www.publico.pt/2020/07/17/desporto/noticia/cidade-desportiva-sp-braga-custara-335-milhoeseuros-1924923 (Accessed: 8 September 2021).

Maia, G. and Grande, N. (2020) 'Interview - Eduardo Souto de Moura'.

Müller, M. (2015) 'What makes an event a mega-event? Definitions and sizes', Leisure Studies, 34(6), pp. 627-642. doi:10.1080/02614367.2014.993333.

Observador, A.L. (2019) Câmara de Braga vai fazer referendo para decidir se vende o estádio municipal, Observador. Available at: https://observador.pt/2019/02/11/camara-de-braga-vai-fazer-referendo-paradecidir-se-vende-o-estadio-municipal/ (Accessed: 8 September 2021).

Presidência do Conselho de Ministros (1998) Resolução do Conselho de Ministros 117/98, Diário da República Eletrónico. Available at: https://dre.pt/web/guest/pesquisa//search/241455/details/normal?filterEnd=2004-12-31\&filterStart=1998-09-

03\&filterAction=TRUE\&q=uefa\&fqs=braga\&fqs=uefa\&perPage=25 (Accessed: 26 August 2021).

RTP (1999) 'Portugal eleito organizador do Euro 2004', 12 October. Available at: https://arquivos.rtp.pt/conteudos/portugal-eleito-organizador-do-euro-2004/ (Accessed: 8 September 2021).

SIC (2013) Vítor Sousa assume derrota no fim da era Mesquita Machado em Braga, SIC Notícias. Available at: https://sicnoticias.pt/especiais/2013/autarquicas2013/2013-09-29-Vitor-Sousa-assume-derrota-nofim-da-era-Mesquita-Machado-em-Braga (Accessed: 8 September 2021).

Tribuna Expresso (2021) António Salvador quer regressar ao Estádio $1 .^{\circ}$ de Maio. Abandono da Pedreira gera tensão entre Câmara e Sporting de Braga, Tribuna Expresso. Available at: //tribunaexpresso.pt/futebol-nacional/2021-04-23-Antonio-Salvador-quer-regressar-ao-Estadio-1.-deMaio--Abandono-da-Pedreira-gera-tensao-entre-Camara-e-Sporting-de-Braga-54b2a7ee (Accessed: 2 September 2021).

UEFA (2000) uefa.com. Available at: https://web.archive.org/web/20000621142305/http://www.uefa.com/euro/2004/bid.asp?Country=Por\& Page=intro.html (Accessed: 8 September 2021).

Viseu, J. et al. (2004) Avaliação do impacto económico do Euro 2004: relatório final.

Vogwell, D (2003) 'Stakeholder management', in. $P M I^{\circledR}$ Global Congress 2003-EMEA, The Hague, South Holland, The Netherlands.: Project Management Institute. 